\title{
The social and scientifical evolution of the cosmetic science - a brasilein view
}

\author{
A evolução social e científica da ciência cosmética - uma visão brasileira
}

\author{
Victor Hugo Pacagnelli Infante; Maísa Oliveira de Melo; Patrícia M. B. G. Maia Campos \\ School of Pharmaceutical Sciences of Ribeirão Preto - University of São Paulo \\ E-mail: victorpinfante@gmail.com
}

\begin{abstract}
The research and development of cosmetic products is closely related to society modifications, as it must fulfil constantly changing consumer needs. More than only using, people often seek the cosmetic market to express their individuality in a varied way. For the development of this study, a bibliographical review of the pertinent literature related to the cosmetic market was carried out. In addition, articles and books related to beauty, vanity and consumption were consulted to obtain information about the social and political changes that could influence the cosmetic market. From classic hygiene products to luxury articles, political expression of sexuality and feminine power, cosmetics followed the social evolutions of products that enslaved women, reaching a position of female empowerment, for example. It is also necessary to emphasize that men have changed their way of facing vanity and masculinity, utilization more cosmetics. Within this perspective, it became apparent how behavioural patterns of certain decades reflected on cosmetic choices and vice versa. In addition, it is possible to notice that the cosmetic market presents a potential more than merely commercial: it defines generations and assists in the process of understanding our own history within the perspective of beauty and social acceptance.
\end{abstract}

Keywords: cosmetics, culture, consume.

\section{Resumo}

A pesquisa e o desenvolvimento de produtos cosméticos está intimamente relacionada com as modificações da sociedade, pois devem satisfazer as necessidades do consumidor em constante mudança. Mais do que apenas consumir, as pessoas estão agora buscando o mercado de cosméticos para expressar sua individualidade de maneira variada. Para o desenvolvimento deste estudo, foi realizada uma revisão bibliográfica da literatura relacionada ao mercado de cosméticos dos séculos XX e XXI. Além disso, artigos e livros relacionados à beleza, vaidade e consumo foram consultados para obter informações sobre as mudanças sociais e políticas que poderiam influenciar o mercado de cosméticos. Dos produtos de higiene clássica aos artigos de luxo, os cosméticos seguiram as evoluções sociais dos produtos que escravizavam as mulheres, atingindo a posição de empoderamento feminino, por exemplo. Também é necessário enfatizar que os homens mudaram sua maneira de enfrentar vaidade e masculinidade, consumindo mais cosméticos. Nessa perspectiva, tornou-se evidente como os padrões comportamentais de certas décadas refletiam sobre escolhas cosméticas e vice-versa. Além disso, é possível notar que o mercado de cosméticos apresenta um potencial mais do que meramente comercial: define gerações e auxilia no processo de compreensão de nossa própria história na perspectiva da beleza e aceitação social.

Palavras-chave: cosméticos, cultura, consumo 


\section{Introdution}

The history of cosmetics is long, dating from the beginning of ancient civilizations. Such products are always associated with religious and divine practices, very evident in the Ancient Egypt ${ }^{1}$, for example. During the Middle Ages, the idea passed of a more lively and jovial beauty through makeup products, symbolic of the high nobility, since the hygiene habits of the time were limited.

According to Palacios (2006) cosmetics can serve more than their scientific functions, being also a political, social and cultural statement for the development of products and publicity contextualized with the present moment ${ }^{2}$.

The research and development of cosmetic products is closely related to the society evolution. More than utilization, people often seek the cosmetic market to express their individuality in varied ways, as media influences consumer choice, for example, the figure of metrosexual for male segmentation ${ }^{3,4}$. In addition, political, economic and social scenarios affect how people will consume. Even in times of crisis, it is common that the sale of cosmetics is not dramatically decreased when compared to other markets ${ }^{5,6}$.

Originally with the only function of cleaning and giving body aroma, cosmetics have come to play a very important role in the consumer's self-esteem, acceptance and attraction. There is a general agreement that the modern beauty industry emerged during the second half of the nineteenth century. Increased discretionary income, urbanization, and change in values stimulated rapid growth, especially in the United States. Subsequently, hygienic practices and beauty ideals became widely diffused. The timing, extent, and social and cultural impact of this diffusion remain largely unexplored, since literature is almost non-existent. Changes in how the body is viewed and accepted in Western society helped the market to expand rapidly, especially since the $1950 \mathrm{~s}^{7}$. The evolution of the use of cosmetics followed the advances on studies in the area, resulting in safer and more effective products ${ }^{8}$.

\section{Objective}

The present article elucidates the evolution of the cosmetic area with a social approach, focusing on the history of utilization and its influence in the beauty sector, showing the evolution of the male market, a prominent

\section{Introdução}

A história do cosmético é longa e datada desde o início das antigas civilizações e esses produtos estão sempre associados a práticas religiosas e divinas, sendo muito evidentes no antigo Egito ${ }^{1}$, por exemplo. Através dos produtos de maquiagem, durante a Idade Média, passava-se a ideia de uma beleza mais viva e jovial, símbolo da alta nobreza, uma vez que os hábitos de higiene da época não eram tão presentes.

De acordo com Palacios (2006), os cosméticos podem ser mais do que sua função científica, sendo também uma declaração política, social e cultural para o desenvolvimento de produtos e publicidade contextualizada com o momento presente ${ }^{2}$.

A pesquisa e o desenvolvimento de produtos cosméticos estão intimamente relacionados com a evolução da sociedade. Mais do que consumindo, as pessoas procuram o mercado de cosméticos para expressar sua individualidade de maneira variada, à medida que a mídia influencia na escolha do consumidor, por exemplo, a figura de metrosexual para segmentação masculina ${ }^{3,4}$. Além disso, os cenários políticos, econômicos e sociais afetam a forma como as pessoas irão consumir. Mesmo em tempos de crise, é comum que a venda de cosméticos não sofra grandes quedas quando comparada a outros mercados ${ }^{5,6}$.

Originalmente com a única função de limpar e dar aroma ao corpo, os cosméticos passaram a desempenhar um papel muito importante na auto-estima, aceitação e atração do consumidor. Existe um consenso geral de que uma indústria de beleza moderna surgiu durante a segunda metade do século XIX. O aumento da renda discricionária, a urbanização e a mudança de valores estimularam o rápido crescimento, principalmente nos Estados Unidos. Posteriormente, práticas de higiene e ideais de beleza tornaram-se amplamente difundidos. O momento, a extensão e o impacto social e cultural dessa difusão permanecem amplamente inexplorados, uma vez que a literatura é quase inexistente. As mudanças na forma como o corpo é visto e aceito na sociedade ocidental ajudaram o mercado a se expandir rapidamente, especialmente desde a década de $1950 \mathrm{~s}^{7}$. A evolução do uso de cosméticos seguiu os avanços em estudos na área, resultando em produtos mais seguros e efetivos ${ }^{8}$.

\section{Objetivo}

O presente artigo elucida a evolução da área cosmética com uma abordagem social, com foco na história do consumo e sua influência no setor da beleza, mostrando aevolução do mercado masculino, um segmento proe- 
segment of the cosmetic area, as well as the changes that drove utilization among women.

\section{Material and methods}

For the development of this study, a bibliographic review of relevant material related to the cosmetic market was carried out, including information as advertisements, magazines and scientific articles from te twentieth and twenty first centuries. In addition, articles and books related to beauty, vanity and cosmetic utilization were also consulted to obtain information about how the social and political changes can influence the cosmetic market. Behaviour patterns and beauty symbols of each decade were searched and analysed to study how the cosmetic market has evolved in the last century with the conception of beauty.

\section{Results and discussion}

\section{$1900-1920$}

Since the end of the nineteenth century and in the beginning of the twentieth century, men were frequenters of barbershops, where specialized professionals performed the shaving process. This situation began to change in 1901, with the invention of Gillette's portable shaving device in the European market. With this invention, the act of shaving became home-based, and also required products that could aid in the shaving process $^{9}$. At that time, the use of male figures in cosmetic advertisements was unusual or did not feature prominently. Furthermore, people frequently had the habit of rubbing themselves harshly while bathing, associating this process with a good hygiene ${ }^{10}$.

From the mid-nineteenth century, soap powder companies entered the industry. The soap industry grew rapidly as a result of the application of new methods of marketing and mass production ${ }^{7}$.

\section{$1920-1930$}

At this time, Brazil began to experience an urbanization process and with this, some male standards began to be redefined. Masculine beauty and behaviour continued to be related to virility, but at this point, they were associated with cars and sports. During this period, the main complaint in male beauty was associated with baldness, which was seen as a sign of male impotence. Studies about sex hormones and their influence on hair loss and skin affections, such as acne were still scarce ${ }^{11,12}$. minente da área cosmética, bem como as mudanças que impulsionaram o consumo entre as mulheres.

\section{Material e métodos}

Para o desenvolvimento deste estudo, foi realizada uma revisão bibliográfica de material relevante relacionado ao mercado de cosméticos, incluindo informações como propagandas, revistas e artigos científicos dos séculos XX e XXI. Além disso, artigos e livros relacionados à beleza, vaidade e consumo também foram consultados para obter informações sobre como as mudanças sociais e políticas podem influenciar o mercado de cosméticos. Padrões comportamentais e símbolos de beleza de cada década foram pesquisados e analisados para estudar como o mercado de cosméticos evoluiu no século passado com a concepção de beleza.

\section{Resultados e discussão}

\section{$1900-1920$}

Desde o final do século XIX e no início do século XX, os homens eram frequentadores de barbeiros, onde profissionais especializados realizavam o processo de barbear. Esta situação começou a mudar em 1901, com a invenção do dispositivo portátil de barbear da Gillette no mercado europeu. Com este invento, o ato de raspar tornou-se caseiro, o que também requeria produtos que poderiam auxiliar no processo de barbear ${ }^{9}$. Naquela época, o uso de figuras masculinas em propagandas cosméticas era incomum ou não fazia parte proeminente. Além disso, as pessoas frequentemente tinham o hábito de esfregar-se com dureza ao se banharem, associando esse processo a uma boa higiene ${ }^{10}$.

A partir de meados do século XIX, empresas de sabão em pó entraram no setor de sabonetes. A indústria de sabão cresceu rapidamente como resultado da aplicação dos novos métodos de marketing e produção em $\operatorname{massa}^{7}$.

\section{$1920-1930$}

Neste momento, o Brasil começou a experimentar um processo de urbanização e, com isso, alguns padrões masculinos começaram a ser redefinidos. A beleza e o comportamento masculinos continuaram relacionados à virilidade, mas neste momento, eles estavam associados a carros e esportes. Durante este período, a principal queixa na beleza masculina foi associada à calvície, que foi vista como um sinal de impotência. Estudos sobre hormônios sexuais e sua influência na perda de cabelo e 
After the World War I, the lacquer technology (based on films formed by nitrocellulose) was created, which led to the introduction of nail polish in the market. Additionally, another very important cosmetic product was introduced to the public: lipsticks ${ }^{9,13}$. However these products are more correlated with female public.

The cosmetic industry began to use synthetic versions of natural compounds (lavender, for example) on its products, which were an important step to be applied on future applications ${ }^{14}$.

At the end of this decade, the stock market crash of 1929 occurred in the United States, an economic crisis affecting the whole world and changing the way that publicity was made and presented to the public.

\section{$1930-1940$}

In this period, the so-called "between wars" and American post-recession, it was necessary to redefine how the products would be transmitted to public. This way, campaigns and publicity pieces were redesigned to transmit happiness and joy, mainly using pattern beauties $^{15}$. Plastic surgeries became popular, associating the beauty ideal with increased self-esteem and wellbeing ${ }^{16}$.

In 1932, the American company Revlon developed a nail polish with colour, by adding pigments to the lacquer, forming a coloured film on the nail ${ }^{13}$. In 1936 the French company L'Óreal developed one of the first sunscreens. This product was based on olive oil extract and tincture of iodine and promised a certain sun protection. At that time, there were no relevant studies that related the effect of sun exposure with photoaging or skin cancer. The use of sunscreens had a beautifying purpose, not as a protective product, as it is today ${ }^{9}$. In the same year, the first facial foundation was developed, providing a good coverage and facial colour correction. Simultaneously, these products started to be introduced in special characteristics to be used in theatre ${ }^{13}$.

In the 1938, the U.S. Federal Food, Drug, and Cosmetic Act was passed by Congress, and cosmetics were defined proposed as products for adornment or beautification, but not affecting the structure or function of skin. It is important to highlight that besides the fact that this definition is still in use, nowadays ( $21^{\text {st }}$ century) it is not well accepted considering that products designed for aging skin or simply hydration can penetrate on skin ${ }^{17}$. American companies began to produce the first products for males in large scale. These products were basically hair preparations, such as gels. Previously produced in pharmacies, their availability now spread a hairstyle among men ${ }^{7}$. afecções da pele, como a acne ainda eram escassos ${ }^{11,12}$. Após a Primeira Guerra Mundial, foi criada a tecnologia da laca (baseada em filmes formados por nitrocelulose), o que levou à introdução do esmalte de unhas no mercado. Além disso, outro produto cosmético muito importante foi apresentado ao público: batons ${ }^{9,13}$. Entretanto, esses produtos eram mais associados ao público feminino.

A indústria de cosméticos começou a usar a síntese de compostos naturais (lavanda, por exemplo) em seus produtos, que foram um passo importante a ser aplicado em futuras aplicações ${ }^{14}$.

No final desta década, a crise de 29 aconteceu nos Estados Unidos, afetando todo o mundo, mudando a forma como a publicidade foi feita e apresentada ao público.

\section{0-1940}

Neste período, o chamado "entre guerras" e pós-recessão americana, foi necessário redefinir como os produtos seriam transmitidos ao público. Desta forma, as campanhas e peças publicitárias foram redesenhadas para transmitir felicidade e alegria ${ }^{15}$. As cirurgias plásticas tornaram-se populares, associando o ideal da beleza com maior auto-estima e bem-estar ${ }^{16}$.

Em 1932, a empresa americana Revlon desenvolveu um esmalte com cor, adicionando pigmentos à laca, formando um filme colorido na unha ${ }^{13}$. Em 1936, o francês L'Óreal desenvolveu um dos primeiros protetores solares. Este produto foi baseado em extracto de azeite e tintura de iodo e prometeu certa proteção solar. Naquele momento, não havia estudos relevantes que relatassem o efeito da exposição ao sol com fotoenvelhecimento ou câncer de pele. $\mathrm{O}$ uso de protetores solares teve um propósito de embelezamento, não como um produto protetor, como é hoje ${ }^{9}$. No mesmo ano, a primeira base facial foi desenvolvida, proporcionando uma boa cobertura e correção de cor facial. Simultaneamente, esses produtos também começaram a ser introduzidos em características especiais para serem usadas em teatro ${ }^{13}$. No Ato do Congresso de 1938, a definição de cosméticos foi proposta como "produtos para adorno e embelezamento, não afetando a estrutura e a função da pele". É importante ressaltar que, além do fato de que essa definição ainda está em uso, hoje em dia (século 21), não é bem aceita, considerando que os produtos para envelhecimento da pele ou simplesmente a hidratação podem penetrar na pele ${ }^{17}$.

Nessa década empresas americanas começaram a produzir os primeiros produtos masculinos em larga escala. Esses produtos eram basicamente preparações para o cabelo, como géis e brilhantinas. Antes eram produzidos em boticas e farmácias, agora difundem um estilo 
$1940-1950$

It was the period of the World War II, and during this process woman gained more space in the labour market because many men were on the warfronts. This period is important because, with the end of the war, there was a polarization in the world between two distinct models of government: capitalist and socialist; being an important point for a consumer-based society.

Within this social structure, advertisements would gain more space and the use of psychological resources in advertisements was significant for the popularization of cosmetics, such as the use of colours to arouse the desired emotions in the consumer, not just on the advertisements but on the products itself as well ${ }^{18}$.

The research regarding possible adverse reactions caused by cosmetic products began, as the irritating action of certain soaps, for example. This way, manufacturers began to choose their raw materials according to their safety, in order to avoid possible irritations ${ }^{19}$. Studies with cosmetics, not just to beautify but to change some skin conditions on skin such as wrinkles, started to gain importance ${ }^{20}$.

For men, a standard of beauty related to the soldiers, virile and muscular, was valued. The main cosmetic products used by this public were the grease hair colognes and body colognes ${ }^{9}$.

\section{0-1960}

It was the period of American cinema expansion and along with it, the patterns associated with beauty and behaviour. If for men the beauty standard were defined by James Dean (representing the youth) and Clark Gable (representing a more classical man), for women we can cite Marilyn Monroe as the standard of eroticization of the female body. It was not long before advertisements in cosmetics transmitted this behavioural standard ${ }^{9,21,22}$.

During this period, the Barbie Mattel doll and her beauty pattern spread, boosting the beauty and vanity range even among children. Barbie's boyfriend Ken appeared years later and would also boost the process of grooming among men ${ }^{7,9}$.

The process of urbanization in Brazil increased during this period, with the transfer of the countries' capital to the interior. It is important to highlight that in this process there is an increase in the consumption of hygiene cosmetics in the country, a practice associated with the urban environment. This is also the period after World War II , where the world economy begins to grow again, especially in the United States ${ }^{9,10}$.

The Brazilian man has often found a sexist barrier to the use of cosmetics and, in this way, there is a direct de penteado entre os homens ${ }^{7}$.

\section{$1940-1950$}

Foi o período da Segunda Guerra Mundial e durante este processo a mulher ganhou mais espaço no mercado de trabalho porque os homens estavam nas frentes da guerra. Este período é importante porque, com o fim da guerra, houve uma polarização no mundo entre dois modelos de governo distintos: capitalistas e socialistas; sendo um ponto importante para uma sociedade de consumo.

Dentro desta estrutura social, as propagandas ganhariam mais espaço e o uso de recursos psicológicos em propagandas era significativo para a popularização de cosméticos, como o uso de cores para despertar as emoções desejadas no consumidor, não apenas sobre os anúncios, mas sobre os produtos também ${ }^{18}$.

O estudo das possíveis reacções adversas causadas por produtos cosméticos começou a ser pesquisado, como a ação irritante de certos sabões, por exemplo. Desta forma, os fabricantes começaram a escolher suas matérias-primas de acordo com sua segurança, a fim de evitar possíveis irritações ${ }^{19}$. Estudos com cosméticos, não apenas para embelezar, mas para mudar algumas condições de pele na pele, como rugas, começaram a ganhar importância ${ }^{20}$.

Para os homens, foi avaliado um padrão de beleza relacionado aos soldados, viril e musculoso. Os principais produtos cosméticos utilizados por este público foram a brilhantina, as colônias e as águas de colônia ${ }^{9}$.

\section{$950-1960$}

Foi o período de expansão do cinema americano e, juntamente com ele, os padrões associados à beleza e ao comportamento. Se, para homens, fosse definido por James Dean (representando a juventude) e Clark Gable, representando um visual mais clássico, para mulheres, podemos citar Marilyn Monroe como padrão de erotização do corpo feminino. Não demorou muito para propagandas em cosméticos, transmitissem esse padrão comportamental ${ }^{9,21,22}$.

Nesse período difunde-se a boneca Barbie Mattel e seu padrão de beleza, impulsionando o emrcado de beleza e vaidade mesmo entre as crianças. Anos mais tarde surgiria o Ken, namorado da Barbie que também impulsionaria o processo de grooming entre os homens ${ }^{7,9}$.

O Brasil é marcado um processo de urbanização crescente a partir deste período, com transferência da capital do país para o interior. É importante destacar que nesse processo há um aumento no consumo de cosméticos de higiene no país, uma prática associado ao meio urbano. É aqui também o período pós segunda guerra 
impact on his quality of life ${ }^{4}$. During this period, with advertising campaigns on the rise, the cigarette industry has grown dramatically. This directly affected the health and skin quality of boys, since smoking is closely related to the process of premature skin aging. However, the idea of cigarette use was associated with an image of joviality and, often, virility ${ }^{23}$.

\section{0-1970}

In 1960, L'Oreal launched the first hairspray, which changed the women's hair care routine, whether in salons or in their residences. Another change in the cosmetic industry was the incorporation of makeup products aimed at the eye area, such as mascara and eyeshadows. It is also in this period the unisex concept emerged, originated mainly from the high fashion community with the incorporation of suits in the feminine environment by Yves Saint Laurent, for example ${ }^{9,13}$.

On this decade, the effects of cosmetics were studied to elucidate their effects at a cellular level. The use of preservatives on cosmetics started to gain prominence, highlighting their importance within these products ${ }^{24}$.

Also in 1960, the first European congress of skin aging took place, changing how the cosmetic industry observed the aging process and how experts understood wrinkles and lines of expression ${ }^{9,25}$.

In that same year, the first female contraceptive pill appeared on the market, a mark in women's history. Thereby, women could now decide whether they want to have children or not, and even if they did, there was a possibility to reconcile career with motherhood. The decrease in the birth rate brought other important points, as a higher income per capita in families, which led to the purchase of products that were considered useless until then: cosmetics. For this reason, practical packages for handbags were developed, so women who were working and had an intense daily routine could still take care of their appearance.

In this context, it is possible to observe the "boom" of the consumer society, accompanied by the way cosmetics were used and advertised. Also, the sensorial properties and their influence in the use of cosmetics started to be studied. With the association of cosmetics with comfort, the act of rubbing and cleaning the skin aggressively was no longer related to these new cosmetic products $^{9,26}$

Furthermore, sun exposure was often intense and sun protection was almost non-existent, which led to a culture that is perpetuated to present day society and helped to increase the incidence of skin neoplasm conditions $^{27,28}$. As a consequence, studies have shown that the Brazilian mature skin suffered the consequences of mundial, onde a economia mundial começa a crescer novamente em especial a norte americana ${ }^{9,10}$.

O homem brasileiro sempre encontrou uma barreira machista para a utilização de cosméticos e, desta forma, há um impacto direto em sua qualidade de vida ${ }^{4}$. Nesse período, com as campanhas publicitárias em alta, a indústria do cigarro cresceu vertiginosamente. Isso afetou diretamente a saúde e a qualidade da pele dos rapazes, uma vez que o tabagismo está intimamente relacionado com o processo de envelhecimento cutâneo precoce. Entretanto, a ideia de consumo dos cigarros estava associada a uma imagem de jovialidade e, muitas vezes, virilidade $^{23}$.

1960-1970

Em 1960, L'Oreal lançou o primeiro spray para o cabelo, que alterou a rotina de cuidados com as mulheres, seja em salões ou em suas residências. Outra mudança na indústria de cosméticos foi a incorporação de produtos de maquiagem destinados à área dos olhos, como rímel e sombras oculares. Também neste período surgiu o conceito unisex, originado principalmente da comunidade de alta moda com a incorporação de ternos no ambiente feminino por Yvés Saint Laurent, por exemplo $^{9,13}$.

Nesta década, os efeitos dos cosméticos foram estudados para elucidar seus efeitos a nível celular. O uso de conservantes em cosméticos começou a ganhar destaque, destacando a importância desses produtos ${ }^{24}$.

Também em 1960, ocorreu o primeiro congresso europeu de envelhecimento da pele, mudando a forma como a indústria de cosméticos observou o processo de envelhecimento e como os especialistas entenderam rugas e linhas de expressão $0^{9,25}$

No mesmo ano, a primeira pílula contraceptiva feminina apareceu no mercado, uma marca na história das mulheres. Assim, as mulheres agora podem decidir se querem ter filhos ou não, e mesmo que o façam, existe a possibilidade de reconciliar a carreira com a maternidade. A diminuição da taxa de natalidade trouxe outros pontos importantes, como uma maior renda per capita nas famílias, o que levou ao consumo de produtos considerados inúteis até então: cosméticos. Por esse motivo, pacotes práticos para bolsas foram desenvolvidos, então as mulheres que trabalhavam e tiveram uma rotina intensa ainda podem cuidar de sua aparência.

Neste contexto, é possível observar o "boom" da sociedade de consumo, acompanhado pela forma como os cosméticos foram consumidos e anunciados. Além disso, as propriedades sensoriais e sua influência no uso de cosméticos começaram a ser estudadas. Com a associação de cosméticos com conforto, o ato de esfregar e 
this excessive sun exposure, presenting more photodamaged areas than the French skin, for example ${ }^{29}$.

\section{0-1980}

The U.S. was in the Vietnam War, along with the Cold War period, and the polarization between the capitalist and socialist systems was reflected on the forms of expression of beauty, more specifically in the expression male beauty, as the use of beards, for example. At that time, having a longer beard could be related to the figure of Che Guevara, an important socialist figure. Thus, for the capitalist culture, the non-shaved aspect took the form of political expression and resistance ${ }^{30,31}$.

In the cosmetic area, hair conditioners appeared. In addition, the scientific appeal appeared in advertisements for cosmetics, driven by the development of the methods to evaluate the skin conditions as well as sensory studies area. In the late 1970 s, Johnson \& Johnson launched the Sundown ${ }^{\circledR}$ photo protector with SPF $15^{9}$.

1980-1990

In the end of the 1980 decade and the beginning of 90's, there was a radical change in the world with the fall of the Berlin Wall: the end of bipolarity capitalism vs. socialism, which ended with the "victory" of capitalism as the dominant economic structure. Also in this decade the media was better structured, which resulted in a more globalized world at the end of the 20th centu$r^{32}$. This scenario was very important for the cosmetic industry, since capitalism sells an idea of individuality expression, which can be associated with the use of cosmetics.

In this period, LGBT movements were structured, mainly in the U.S., which lead to a redefinition of sexuality and expression, influenced by pop culture, reaching its peak with figures like Madonna and David Bowie, which expanded even more the definitions of gender, reflecting on the expressive use of make-up by both genders ${ }^{33}$.

In the late 1980s, with the boom of AIDS, it was necessary to rethink the advertisement pattern, since they were often very focused on erotization. Sex became a public health problem and a healthy lifestyle ideal as a marketing campaign was initiated. The cosmetic industry soon began to absorb this endorsement, especially in 1981, when the use Vitamin A as an active ingredient in cosmetics started, with the promise of improvement of the overall skin condition and anti-aging properties 9 . It is necessary to emphasize that until now the products used by the masculine public were basically of personal hygiene or of shaving. Skin care was still very scarce in this sector of the population and the use of photoprotec- limpar a pele de forma agressiva não estava mais relacionado a esses novos produtos cosméticos ${ }^{9,26}$.

Além disso, a exposição ao sol era intensa e a proteção era quase inexistente, o que levou a uma cultura que se perpetua até o presente dia na sociedade e ajuda a aumentar a incidência de condições de neoplasia da pele ${ }^{27}$, ${ }^{28}$. Estudos mostraram que a pele madura brasileira sofria as consequências dessa exposição excessiva ao sol, apresentando mais áreas com danificadas pelo sol do que, por exemplo, a pele francesa ${ }^{29}$.

\section{$1970-1980$}

Os EUA estavam na Guerra do Vietnã, juntamente com o período da Guerra Fria, onde a polarização entre os sistemas capitalistas e socialistas refletiu sobre as formas de expressão da beleza, mais especificamente na expressão beleza masculina, como o uso de barbas, por exemplo. Naquele momento, ter uma barba mais longa poderia estar relacionada com a figura de Che Guevara, uma importante figura socialista. Assim, para a cultura capitalista, o aspecto não raspado assumiu a forma de expressão política e resistência ${ }^{30,31}$.

$\mathrm{Na}$ área cosmética apareceram os condicionadores capilares. Além disso, o apelo científico aparece em anúncios de cosméticos, impulsionados pelo desenvolvimento dos métodos para avaliar as condições da pele, bem como a área de estudos sensoriais. No final da década de 1970, a Johnson \& Johnson lançou o protetor solar Sundown ${ }^{\circledR}$ com FPS $15^{9}$.

\section{0-1990}

Na fim da década de 1980 e começo dos anos 90, houve uma mudança radical no mundo com a queda do Muro de Berlim: o fim da bipolaridade do capitalismo versus o socialismo, que terminou com a "vitória" do capitalismo como estrutura econômica dominante. Também nesta década, a mídia foi melhor estruturada, o que resultou em um mundo mais globalizado no final do século $\mathrm{XX}^{32}$. Este cenário era muito importante para a indústria cosmética, já que o capitalismo vende uma idéia de expressão individual, que pode ser associada ao uso de cosméticos.

Neste período, os movimentos LGBT foram estruturados, principalmente nos EUA, que levaram a uma redefinição da sexualidade e expressão, influenciada pela cultura pop, atingindo seu pico com figuras como Madonna e David Bowie, que expandiram ainda mais as redefinições de gênero, refletindo sobre o uso expressivo de maquiagem por ambos os sexos ${ }^{33}$.

No final da década de 1980, com o boom da AIDS, foi necessário repensar o padrão de propaganda, já que eles estavam muito focados na erotização. O sexo tornou-se 
tives was not widespread. Even among women, its use was not yet representative.

\section{0-2000}

Since the late 1980s and throughout the 1990s, male consumption of cosmetics began to grow, mainly with personal hygiene and shaving products. Also in this decade, the first specific cosmetic products for men appeared, as moisturizers, with the premise that male skin is different from the female ${ }^{3}$.

These changes in men's behaviour are partly caused by sociocultural pressures. For example, in today's Western societies, people live in a period of transition from the modern to the postmodern period. Social and technological changes created postmodern conditions that were reflected in consumer behaviour. This was also a feature related to postmodern consumer society ${ }^{7}$.

The baby-boomer generationwas already employed in the 80 's, and began to feel the effects of aging. Due to the fact that this generation had a more stable financial condition and repudiated the aging process, anti-aging products gained space and a stronger consumer market $^{17}$, first among women. Still, in this process there was greater monetary access to cosmetic products and men began using skin care products as well as photoprotectors.

\section{$2000-2010$}

During the 2000s, the search to expand the masculine market increased. The marketing area invested in the figure of a metrosexual man, which were associated with vanity and beauty care, without losing the masculinity. This type of a cosmopolitan man was very well accepted by different sectors of society and their image was associated with football stars, such as David Beckham, and eventually spread an idea of skin care among the male sector, mainly within the sexist and conservative community, which was also observed in Brazil ${ }^{34}$.

In this period, with the legalization of gay marriage and laws for LGBT rights in several countries, a strong humanization of the LGBT movement also happened, which meant that the society began to see this community in a more dignified and equal way.

The use of cosmetics by men has long been associated with a homosexual figure. A greater humanization of the movement brought a lower rejection of the characteristics formerly associated with homosexual men, as the grooming process became a reality among men apart from their sexual orientation, being more related to an individual expression, that is, if man is willing to use cosmetics this does not necessarily reflect his sexuality but his personal desire ${ }^{4,35}$. um problema de saúde pública e um ideal de estilo de vida saudável como campanha de marketing foi iniciado. A indústria de cosméticos logo começou a absorver esse endosso, especialmente em 1981, quando o uso de Vitamina A como ingrediente ativo em cosméticos começou, com a promessa de melhoria da condição geral da pele e antienvelhecimento9.

É necessário destacar que até aqui os produtos utilizados pelo público masculino eram basicamente de higiene pessoal ou de barbear. O skin care ainda era muito escasso nesse setor da população e a utilização de fotoprotetor também não era difundida (mesmo entre as mulheres ainda não era representativo).

\section{0-2000}

Desde o final da década de 1980 e durante a década de 1990, o consumo masculino de cosméticos começou a crescer, principalmente com produtos de higiene pessoal e de barbear. Também nesta década, os primeiros produtos cosméticos específicos para homens apareceram, como hidratantes, com a premissa de que a pele masculina é diferente da feminina ${ }^{3}$.

Essas mudanças nos comportamentos dos homens são parcialmente causadas por pressões socioculturais. Por exemplo, nas sociedades ocidentais atuais, as pessoas vivem em um período de transição do período moderno para o pós-moderno. Mudanças sociais e tecnológicas criam condições pós-modernas que se refletem no comportamento do consumidor. Essa também é uma característica relacionada com a sociedade de consumo pós moderna. A geração chamada baby boomers, que são aqueles que já trabalharam na década de 80 , e começaram a sentir os efeitos do envelhecimento. Devido ao fato de que esta geração tem uma condição financeira mais estável e repudia o processo de envelhecimento, os produtos antienvelhecimento ganharam espaço e um mercado consumidor mais forte, principalmente entre as mulheres em um primeiro momento ${ }^{17}$. Ainda, nesse processo há um maior acesso monetário aos produtos cosméticos e os homens começaram a utilizar produtos de skin care, bem como fotoprotetores.

\section{$2000-2010$}

Durante os anos 2000, houve uma expansão do mercado masculino. A área de marketing investiu na figura de um homem metrossexual, que estava associado com vaidade e cuidado de beleza, sem perder a masculinidade. Este tipo de homem cosmopolita foi muito bem aceito por diferentes setores da sociedade e sua imagem foi associada às estrelas do futebol, como David Beckham e, eventualmente, espalhar uma ideia do cuidado da pele entre o setor masculino, principalmente dentro 
In 2008, during the global (economic) crisis, an increase in the sale of makeup products in the United States and England, even during a recession, was observed. This process became known as the "lipstick effect" and is related specifically to the increase in sales of makeup products for women, ensuring this way, their image in a corporate market and also guaranteeing a better presentation in job interviews. Still, this crisis was important to further fuel the competition between men and women for job positions, a situation that had a male hegemony in the past ${ }^{6}$.

Furthermore, an expansion of social networks like Orkut, YouTube, Instagram and Facebook started. These platforms became very important in the publicity of cosmetic products from the 2010 s, in addition to increasing consumption ${ }^{36}$.

\section{$2010-2018$}

The wide use of social networks is of immense importance in the current context, being extremely useful in the dissemination of new cosmetic products. Social media also gave strength to the feminist movement, in addition to the endorsement of celebrities. In 2014, the use of red lipstick, which used to be a taboo, became a strong source of discussion between several YouTubers and bloggers, being a landmark of women's freedom of choice $^{37}$

During this period, the black movement also became prominent, showing and highlighting the beauty of the black woman. In this perspective, which was once neglected, the cosmetic market also segmented for this public ${ }^{38}$.

The discussion about the definition of gender also gained space in social media and, of course, reflected in the cosmetics products advertising. Within this sector, the advertisements were done in way to explore the figures of transsexual and drag queen models, for example.

It is important to emphasize that modern men is now seeking not only a certain profile of beauty, moved by a more fluid society, which is explained by Baumann. In his theory, society today does not only seek a pattern of behaviour, but is more liquid and oriented towards consumption $^{39}$.

Nevertheless, some masculine aesthetic features are currently prominent. For example, coloured hair, even if subtle, is a very common reality. In addition, the use of beards and long hair are also popular styles, being a highlight in the research and development of products for the treatment and modification of these epidermal attachments ${ }^{40}$.

The male skin aging process has also gained promi- da comunidade sexista e conservadora, o que também foi observado no Brasil ${ }^{34}$.

Neste período, com a legalização do casamento gay e as leis para os direitos LGBT em vários países, também ocorreu uma forte humanização do movimento LGBT, o que significou que a sociedade começou a ver essa comunidade de maneira mais digna e igual.O uso de cosméticos por homens tem sido associado há muito tempo a uma figura homossexual. Uma maior humanização do movimento trouxe uma menor rejeição das características anteriormente associadas aos homens homossexuais, já que o processo de grooming tornou-se uma realidade entre os homens, além da orientação sexual, sendo mais relacionado a uma expressão individual, ou seja, se o homem estiver disposto a usar cosméticos, isso não reflete necessariamente sua sexualidade, mas seu desejo pessoal ${ }^{4,35}$.

Em 2008, durante a crise global, observou-se um aumento na venda de produtos de maquiagem nos Estados Unidos e na Inglaterra, mesmo durante uma recessão. Este processo tornou-se conhecido como o "efeito lipstick" e está relacionado especificamente ao aumento das vendas de produtos de maquiagem para mulheres, assegurando assim a imagem em frente ao mercado corporativo e também garantindo uma melhor apresentação nas entrevistas de trabalho. Ainda assim, esta crise foi importante para alimentar ainda mais a concorrência entre homens e mulheres para ocupar cargos, uma situação que tinha uma hegemonia masculina no passado ${ }^{6}$.

Além disso, uma expansão de redes sociais como Orkut, YouTube, Instagram e Facebook começou. Essas plataformas tornaram-se muito importantes na publicidade dos produtos cosméticos dos anos 2010, além de aumentar o consumo ${ }^{36}$.

\section{$2010-2018$}

O amplo uso das redes sociais é de imensa importância no contexto atual, sendo extremamente útil na disseminação de novos produtos cosméticos. As mídias sociais também deram força ao movimento feminista, além do endosso de celebridades. Em 2014, o uso do batom vermelho, que costumava ser um tabu, tornou-se uma forte fonte de discussão entre vários youtubers e bloggers, sendo um marco da liberdade de escolha das mulheres 37.

Durante este período, o movimento negro também se tornou proeminente, mostrando e destacando a beleza da mulher negra. Nesta perspectiva, um mercado outrora negligenciado, foi também segmentado para este público ${ }^{38}$. 
nence in the last decade. Once only associated with the female audience, men are now concerned with the appearance and image that appear before society. Maintaining youthful looking skin is a trend among the male audience, which has further boosted the cosmetics market. Postmodern society is marked by an image search that shows health, success and quality of life, so an old and poorly cared for appearance is not desired by this generation ${ }^{41}$.

Recently, in 2016, University of São Paulo was considered the research institution with the largest number of publications in the cosmetic area. This corroborates to illustrate that Brazil is more than a consumer power in this area, investing in high-end research as well ${ }^{42}$.

\section{Conclusions}

Cosmetic products have been present for more than a century, with reports of their use in ancient Greece and Egypt. However, it is important to emphasize that in the last century these products have gained a significant meaning within the context of a consumer society, considering that they are associated with the form of expression of people, being endorsed by celebrities.

More than simply beautifying or improving skin characteristics, such products present a strong social and political appeal within history. The cosmetic market, a billionaire sector of the pharmaceutical industry, has a potential that goes beyond a simply commercial potential: it defines generations and assists in the process of
A discussão sobre a definição de gênero também ganhou espaço nas mídias sociais e, claro, refletida na publicidade de produtos cosméticos. Dentro desse setor, os anúncios foram feitos de maneira a explorar as figuras dos modelos transexuais e drag queen, por exemplo. É importante enfatizar que homens modernos agora buscam não apenas um certo perfil de beleza, movido por uma sociedade mais fluida, explicada por Baumann. $\mathrm{Na}$ sua teoria, a sociedade hoje em dia não busca apenas um padrão de comportamento, mas é mais liquida e orientada para o consumo ${ }^{39}$.

No entanto, algumas características estéticas masculinas estão atualmente proeminentes. Por exemplo, os cabelos coloridos, mesmo que sutis, são uma realidade muito comum. Além disso, o uso de barbas e cabelos longos também são estilos populares, sendo um destaque na pesquisa e desenvolvimento de produtos para tratamento e modificação desses anexos epidérmicos ${ }^{40}$. O processo de envelhecimento cutâneo masculino também ganhou proeminência na última década. Outrora somente associado ao público feminino, agora os homens passam a se preocupar com a aparência e a imagem que transparecem perante a sociedade. Neste interim, manter a pele com aspecto jovem é uma tendência entre o público masculino, o que impulsionou ainda mais o mercado de cosméticos. A sociedade pós moderna é marcada por uma busca de imagem que transpareça saúde, sucesso e qualidade de vida, sendo assim, uma aparência velha e mal cuidada não é desejada por essa geração ${ }^{41}$.

Recentemente, em 2016, a Universidade de São Paulo foi considerada a instituição de pesquisa com o maior número de publicações na área de cosméticos pela Thomson \& Reuters. Isso corrobora para ilustrar que o Brasil é mais do que apenas um poder do consumidor nesta área, investindo também em pesquisas de ponta ${ }^{42}$.

\section{Conclusões}

Os produtos cosméticos estão presentes há mais de um século, com relatos de seu uso na Grécia antiga e no Egito. No entanto, é importante enfatizar que, no século passado, esses produtos ganharam um significativo contexto na sociedade de consumo, considerando que eles estão associados à forma de expressão das pessoas, podendo ser endossados por celebridades.

Mais do que simplesmente embelezar ou melhorar as características da pele, esses produtos apresentam um forte apelo social e político dentro da história. $\mathrm{O}$ mercado cosmético, um setor bilionário da indústria farmacêutica, tem um potencial que vai além do que apenas um potencial comercial: define as gerações e auxilia no 
understanding our own history within the perspective of beauty and social acceptance.

Observing and studying the male consumption of cosmetics is important not only in the administrative area, but also in sociology, since it has a direct effect on the way this public expresses their masculinity in their social environment. In addition, beauty standards have been redefined, modifying the social aspirations of beauty.

It is important to emphasize the need for research in the cosmetic innovation sector: safer products that respect consumer needs are a reality today and should not be discarded. Still, it is vital to reconcile socio-politicaleconomic knowledge with technical knowledge so that the innovations in the sector follow the market trends.

\section{Acknowledgment}

This work was supported by the FAPESP under Grant 2016/13705-0.

\section{Conflit of interests}

The authors declare that there is no financial or personal relationship that can be understood as representing a potential conflict of interest. processo de compreensão de nossa própria história na perspectiva da beleza e da aceitação social.

Observar e estudar o consumo masculino de cosméticos é importante não só na área administrativa, mas também na sociologia, pois tem um efeito direto sobre o modo como esse público expressa sua masculinidade em seu ambiente social. Além disso, os padrões de beleza foram redefinidos, modificando as aspirações sociais da beleza.

É importante enfatizar a necessidade de pesquisas no setor de inovação cosmetica: produtos mais seguros que respeitem as necessidades dos consumidores são hoje uma realidade e não devem ser descartados. Ainda assim, é vital conciliar o conhecimento sócio-político-econômico com o técnico para que as inovações no setor sigam as tendências do mercado.

\section{Agradecimento}

Este trabalho foi apoiado financeiramente pela FAPESP sob processo número 2016 / 13705-0.

\section{Conflito de interesses}

Os autores declaram que não há relação financeira ou pessoal que possa ser entendida como um potencial conflito de interesses. 


\section{References/ Referências}

[1] Walter, Philippe, et al. "Making make-up in Ancient Egypt." Nature 397.6719 (1999): 483.

[2] Palacios, Annamaria da Rocha Jatobá. "Cultura, consumo e segmentação de público em anúncios de cosméticos." (2006).

[3] Close, J-A. "Men's skin care: a sensory perspective." Cosmetics and toiletries 109.2 (1994): 61-65.

[4] Pacagnelli Infante, Victor Hugo, Livia Salomão Calixto, and Patrícia Maria Berardo Gonçalves Maia Campos. "Comportamento de homens e mulheres quanto ao consumo de cosméticos e a importância na indicação de produtos e adesão ao tratamento." Surgical \& Cosmetic Dermatology 8.2 (2016).

[5] Hill, Sarah E., et al. "Boosting beauty in an economic decline: Mating, spending, and the lipstick effect." Journal of personality and social psychology 103.2 (2012): 275.

[6] Elliott, Larry. "Into the red:'Lipstick effect'reveals the true face of the recession." The Guardian 22 (2008): 27.

[7] Jones, Geoffrey. "Blonde and blue-eyed? Globalizing beauty, c. 1945-c. 1980." The Economic History Review 61.1 (2008): 125-154.

[8] Kojima, H. "Trend on alternative to animal testing." International Journal of Cosmetic Science 29.4 (2007): 331-331.

[9] de Sant, Denise Bernuzzi. História da Beleza no Brasil. Editora Contexto, 2015.

[10] Lobo, Tania Haddock. "FACES PINTADAS NO TEMPO: PADRõES DE BELEZA ASSOCIADOS À MAQUIAGEM E SUA EVOLUÇÃO ATRAVÉS DO SÉCULO." (2015).

[11] CORAZZA, Sonia. "A História dos Cosméticos." (2003).

[12] Rohden, Fabíola. "O império dos hormôniose a construção da diferença entre os sexos." História, ciências, saúde-Manguinhos 15 (2008).

[13] Draelos, Zoe Diana. "Cosmetics and skin care products: A historical perspective." Dermatologic clinics 18.4 (2000): 557-559.

[14] TA, H. "Perfumes and Cosmetics: with Especial Reference to Synthetics." Nature 113 (1924): 780.

[15] Trindade, Luís. Foi você que pediu uma história da publicidade?. Tinta da China, 2008.

[16] Loeb, Raul. "História da cirurgia plástica brasileira: 150 anos de evolução." História da cirurgia plástica brasileira: 150 anos de evolução. 1993.

[17] Kligman, Albert M. "Cosmetics: a dermatologist looks to the future: promises and problems." Dermatologic clinics 18.4 (2000): 699-709.

[18] Anderson, Perry. "Balanço do neoliberalismo." Pós-neoliberalismo: as políticas sociais e o Estado democrático. Rio de Janeiro: Paz e Terra (1995): 9-23.

[19] Emery, Byron E., and Leroy D. Edwards. "The pharmacology of soaps II. The irritant action of soaps on human skin." Journal of Pharmaceutical Sciences 29.6 (1940): 251-254.

[20] Kellett, E. G. "The principles and practice of modern cosmetics." Nature 163.4146 (1949): 588.

[21] Rosen, Marjorie. "Popcorn Venus: Women, Movies \& the American Dream." (1973).

[22] Diener, Ed, Derrick Wirtz, and Shigehiro Oishi. "End effects of rated life quality: The James Dean effect." Psychological science 12.2 (2001): $124-128$.

[23] Helfrich, Yolanda R., et al. "Effect of smoking on aging of photoprotected skin: evidence gathered using a new photonumeric scale." Archives of Dermatology 143.3 (2007): 397-402.

[24] Correspondent, A. "Cosmetics: More than Skin Deep." Nature220 (1968): 856.

[25] AYRES, SAMUEL. "Dermal changes following application of chemical cauterants to aging skin: superficial chemosurgery." Archives of Dermatology 82.4 (1960): 578-585.

[26] Isaac, Vera Lucia Borges, et al. "Análise sensorial como ferramenta útil no desenvolvimento de cosméticos." Revista de Ciências Farmacêuticas Básica e Aplicada 33.4 (2013): 479-488.

[27] Pedro, Joana María. "A experiência com contraceptivos no Brasil: uma questão de geração." Revista Brasileira de História 23.45 (2003): $239-260$.

[28] Giesler, Markus, and Ela Veresiu. "Creating the responsible consumer: Moralistic governance regimes and consumer subjectivity." Journal of Consumer Research 41.3 (2014): 840-857.

[29] Mercurio, D. G., et al. "Morphological, structural and biophysical properties of French and Brazilian photoaged skin." British Journal of Dermatology 174.3 (2016): 553-561.

[30] Catoira, Lu. "A construção da estética jovem no cotidiano da contracultura e dos ideais de liberdades políticas, comportamentais, éticas e sexuais." (1968).

[31] Synnott, Anthony. "Truth and Goodness, Mirrors and Masks--Part I: A Sociology of Beauty and the Face." The British Journal of Sociology 40.4 (1989): 607-636.

[32] Pesavento, Sandra Jatahy. História \& história cultural. Autêntica, 2013.

[33] Henderson, Lisa. "Justify our love: Madonna and the politics of queer sex." The Madonna connection: Representational politics, subcultural identities, and cultural theory (1993): 107-128.

[34] Garcia, Wilton. "O corpo contemporâneo: a imagem do metrossexual no Brasil." Mneme-Revista de Humanidades5.11 (2010).

[35] Barber, Kristen. Styling masculinity: Gender, class, and inequality in the men's grooming industry. Rutgers University Press, 2016.

[36] Kozinets, Robert, Anthony Patterson, and Rachel Ashman. "Networks of desire: How technology increases our passion to consume." Journal of Consumer Research 43.5 (2016): 659-682.

[37] Medeiros, Maria Elisa Reinaldo de. "\# NãoTiraOBatomVermelho: como o vlog JoutJout Prazer contribui para a propagação do feminismo nas redes sociais da internet." (2016).

[38] NAVARRO, LUCIANE PEREIRA DA SILVA. "TUDO MUITO CLARO: A IDENTIDADE DA MULHER NEGRA NA PUBLICIDADE BRASILEIRA DE COSMÉTICOS." Revista Mídia \& Contexto-ISSN: 2358-3312 2.1 (2014).

[39] Bauman, Zygmunt. Vida de consumo. Fondo de cultura económica, 2012.

[40] Paasschen, J., et al. "The effect of personal grooming on self-perceived body image." International journal of cosmetic science 37.1 (2015): 108-115.

[41] Dano, F., Roux, E., \& Nyeck, S. (2003). LES HOMMES, LEUR APPARENCE ET LES COSMÉTIQUES: Approche socio-sémioîique. Décisions Marketing, 7-18.

[42] http://stateofinnovation.com/ < accessed on 01st June of 2017> 